PLANTS PEOPLE

POSSIBILITIES

\title{
Horticulture in Belgium
}

Author(s): G. N.

Source: Bulletin of Miscellaneous Information (Royal Botanic Gardens, Kew), Vol. 1893, No. 79 (1893), pp. 162-167

Published by: Springer on behalf of Royal Botanic Gardens, Kew

Stable URL: http://www.jstor.org/stable/4111428

Accessed: 27-06-2016 02:33 UTC

Your use of the JSTOR archive indicates your acceptance of the Terms \& Conditions of Use, available at

http://about.jstor.org/terms

JSTOR is a not-for-profit service that helps scholars, researchers, and students discover, use, and build upon a wide range of content in a trusted digital archive. We use information technology and tools to increase productivity and facilitate new forms of scholarship. For more information about JSTOR, please contact support@jstor.org.

Royal Botanic Gardens, Kew, Springer are collaborating with JSTOR to digitize, preserve and extend access to Bulletin of Miscellaneous Information (Royal Botanic Gardens, Kew) 
by the courteous and sympathetic curator, Mr. Crowther, whose healthy appearance and genial welcome suffice to re-assure him that improvement in his health will soon be accomplished, whilst on every side the eye feasts on the charms of a scientifically laid out and cultivated garden such as can be seen nowhere else in the Colony; here, a noble arenue of stately orange trees, the delicate aroma of whose blossoms perfumes the air ; there, avenue of graceful spondias nodding their leaf-laden branches to the bracing breezes that sweep from over the Akim hills. These, intersected by floral walks and avenues of citrons and oranges, the interspaces thus formed being occupied, here with cacao plants, there with native coffee plants, and elsewhere with Liberian coffee trees; while just in front of the house, neatly arranged rows of beds are covered with flowers of all varieties and shades of colour. The whole thing is so different from what obtains in Accra : the great elevation above the sea, the soft, cool, refreshing breezes, the nights of profound sleep and rest. These are the claims of Aburi as a sanatarium, and only those who have suffered from the sleeplessness of the surf-bound coast towns can realise at its fullest worth the importance of the last of these.

The invalid furniture recently supplied is, indeed, a great boon to the invalids, and is money well spent. 'The crockery, cutlery, and kitchen utensils and table and bed linen require some attention.

I think I ought to add that during my visit there were at least six invalids resident in the Basal Mission Sanatarium, five Germans, and one an Englishman. And in the town there were several natives of Accra, some of them my private patients, who were recruiting their health at the station. In addition, three European and several native officials and many other private individuals went up for the Easter holidays, an event quite unprecedented in the annals of Aburi.

In conclusion, I beg to record my grateful appreciation of the unremitting and thoughtfnl kindness of Mr. Crowther to myself and the other invalids at the sanatarium.

$$
\begin{aligned}
& \text { I have, \&c. } \\
& \text { (Signed) } \\
& \begin{array}{l}
\text { J. Farrell EAsMon, } \\
\text { Acting Chief Medical Officer. }
\end{array}
\end{aligned}
$$

\section{CCCXX.-HORTICULTURE IN BELGIUM.}

With the permission of the First Commissioner of Her Majesty's Works and Public Buildings, the Curator of the Royal Gardens, Mr. George Nicholson, A.L.S., was sent to Belgium for the purpose of attending the Thirteenth International Quinquennial Horticultural Exhibition at Ghent (April 16-23) and of visiting the more important horticultural establishments. The following notes give his impressions of the present position of gardening enterprise in Belgium :-

Belgium is a great horticultural country, and Ghent itself one of the busiest and most important centres of gardening on the continent. Nurseries, many of them of very considerable extent, exist by the hundred in its immediate neighbourhood. Owing to various causes, cheap glass, cheap labour, \&c., many plants are grown for trade purposes on an enormous scale and exported to other European countries at a less price than they could be grown by the persons who import them. Azaleas are a case in point. That splendid specimens of Azaleas can be 
grown in this country is evident enough to anyone familiar with our great flower shows, but that beautiful bushy market plants can be produced in the same time and at the same cost as those exported from Belgium is, I believe, impossible. The continental summer allows these to be planted out in beds in the open air, and causes the wood to be thorouginly ripened and the buds to set in a way which cannot obtain with us except in exceptionally favourable seasons. On the other hand, our moister cooler summers enable English gardeners to surpass their continental colleagues with such plants as Nepenthes, Ferns, Heaths, and many hard-wooded plants.

Fashion in horticulture changes in a somewhat arbitrary way, and no one can escape this conclusion by even reading the reports of the exhibitions of less than 20 years ago and those of to-day. Then new plants and collections were much valued, and nurserymen kept for sale large collections of stove and greenhouse plants, which now are hardly to be found outside a botanic garden. Even Camellias, which less than a generation ago were very extensively grown about Ghent, are now not to be seen in some establishments where once they were the principal stock in trade; apparently the dificulty in arranging the cut flowers and the impracticability of cutting largely from the plants is the cause of the disfavour into which they have fallen. New plants too, in the sense of collections of species, are almost ignored in many places, and instead enormous nuinbers of ornamental foliage and flowering plants, belonging sometimes to not more than a score of species, not unfrequently a much less number, are now to be seen.

The International Quinquennial Exhibition is the 13th of the series and the 159th flower show organised by the "La Société Royale d'Agriculture et de Botanique" of Gient. The society was first formed in 1808, and its first exhibition was held in a room of a small inn in 1809 about 100 yards from the site of its present quarters ; a reproduction of this first exhibition as regards the room, \&c., and as far as possible the species and varieties of plants was one of the most interesting features of the Quinquennial of 1888 .

From 1837 exhibitions were held in a large permanent building, but in 1878 temporary structures more vast each succeeding "quinquennial " were built in the grounds. This year one structure admirably built, designed by M. Ed. Pynaert covered a space of more than 2,500 square metres; and arrangements for heating were made so that, had the weather proved cold, the plants contained in it would have been perfectly safe.

Subsidies from the Belgian Government, the Province, the town of Ghent and the subscriptions of the members of the Society furnish the large sum of money necessary to carry out an exhibition on so vast a scale. No entry fees are paid by exhibitors, and the Society makes arrangements with the railway and steamship companies for low freight charges. This year the entries were more numerous than ever, some even were refused for want of space-and some groups of plants which otherwise would have been under cover were placed for effective masses in the open garden. The jury consisting of 184 members, belonging to 15 nationalities, including Russia, Brazil, and Japan, divided into sections had to judge about 660 classes.

The Great Hall, a glass-roofed structure, with an area of 2,200 square metres, was so arranged as to produce a wonderfully fine effect. Large palms, tree-ferns, \&c. were massed irregularly round outer walls and at the foot of the double staircase leading to the upper rooms of the casino. A main curving walk went round the building in front of these 
tall banks of foliage. Eight masses of dwarfer growing plants were arranged in the centre of the hall with a broad central walk and shorter ones leading into the main arteries.

The palms were especially well-grown, large specimens in splendid health in small tubs and pots. Careful attention to watering, and especially in the application of liquid manure, enable the growers to produce beautiful specimens of great size, which can be moved about with comparative ease. Some years ago collections of palms were grown for sale by some of the principal Belgian nurserymen ; now house after house of a single species or of a very few of those best adapted for decorative work, are to be met with, and the rarer kinds of less value from a "furnishing" print of view have almost entirely disappeared. Kentia, Phonix, Cocos, and Livistona are the genera now most frequently represented in nurseries, but in the exhibition a number of fine specimens of Washingtonia and Erythea (imported from the Riviern), Thrinax, Sabal, Rhapis, Pritchardia, Seaforthia. \&c. were to be seen.

In the centre of the great hall, huge specimen Azaleas were so thickly covered with flowers as to hide the leaves. Although in shape the plants were extremely formal, they showed exceptional skill in cultivation. There must havo been considerabie trouble taken in "keeping buck" plants which under any ordinary conditions in such a season as the present wo:ld have been quite out of flower bofore the exhibition opened. We heard of one exhibitor placing blocks of ice in his Azalea house in order to keep rlown the temperature. Careful snading-in some cases moving plants into dark sheds, \&c. - was also rescrted to. Some of the Aroids exhibited were exceptionally fine : a grander lot of Anthurium scherzerianum than that exhibited by $\mathcal{M}$. G. Warocqué was probably never before seen ; the specimens were very large, healthy, and with extraordinarily large inflorescences. The ornamental foliage Aroids were also well represented; these plants are more widely grown as stove decorative plants in Belgium and other continental countries than in Britain. Ferns, with the exception of tree-ferns, which were well shown, were not remarkable; much better groups as regards cultivation and variety are to be scen at any of the large London shows.

Cycads were good and attracted much attention, but they were decidedly inferior, for instance, to those in cultivation in the Palm House at Kew. Fine plants of Caladiums were exhibited in great variety by M. Louis Van Houtte.

The Norfolk Island Pine, Araucaria excelsa, and a number of garden varieties of it were exhibited in the most perfect conlition ; in and around Ghent whole series of houses in many establishments are devoted to the cultivation of this conifer. It is one of the most popular plants for table and conservatory decoration.

In the Central Hall of the Rotunda were exhibited two very wonderful groups of orchids containing many rare choice and valuable varieties of well-known species, and not a few well-grown plants of rare species beautifully flowered. The two exhibitors were MM, J. Hye and G. Warocqué, both Belgian amateurs.

A collection, said to contain 228 distinct species, many of them uncommon, was exhibited by M. Alfred Van Imschoot; amongst them was a Vanilla in fruit.

Both at the exhibition and in many of the nurseries visited, the English visitor could not help being struck by the health and vigour of Cattleyas, Odontoglossums, Miltonias, and other orchids. Whether the extreme vigour of the plants conduces to longevity (many orchids are short lived under cultivation) is a question which many would like to see definitely settled. As a rule a inuch higher temperature is main- 
tained in the houses than is considered good for the same species under cultivation in English orchid houses.

Canvas is not used in Belgium as a shading material, but thin laths or bamboo strips wired together and drawn up or let down by means of rollers, as are the canvas blinds in England. As a consequence during sunlight the orchid leaves are barred transversely with bands of light and shade quite different from the more diffused light caused by canvas. I cannot but think that this may have something to do with the success wisich attends the cultivation of Cattleyas, Odontoglossums, \&c. in Bcloium.

No thrips or other insect pest infested any of the numerous sets of plants scen; on inquiry this was attributed to a layer of the midribs of tobacco leaves placed on the hot water pipes; fumigation was not resorted to.

In the class for New Plants Messrs. Sander \& Co., St. Albans, exhibited Dracona sanderiana, a distiuct plant with elegant yellow and green leaves, from the Cameroon Mountains; D. godseffiana from the Gold Coast, rewarkable for its prettily spotted foliage and an ally of $D$. surculosa ; Ludovia crenifolia, a Carludovica-like plant from Tropical America; Alocasia watsoniana from Sumatra; Alsophila atrovirens, a beautiful tree fern from South America, and Strobilanthes dyerianus, an East Indian Acanthad with brilliant purple-red leaves and erect spikes of blue flowers. L'Horticulture Internationale, Brussels (M. Linden). showed Eulophiella Elizabetha from Madagascar, a new genus of orchids, with large beautiful flowers; Tradescantia Regine and $T$. superba, beautiful tropical ornamental-leaved species; Smilax argyroea, a small elegant-leaved climber mottled with-silvery grey; Hcemanthus Lindeni, a handsome plant with a head of brilliant crimson flowers not unlike $\boldsymbol{H}$. multiflorus, and Begonia Lansbergia, a noble plant with large emerald green hairy leaves.

The Hippeastrums shown by Messrs. James Veitch \& Sons, Chelsea, were remarkably fine, much better than those of any other exhibitor. The Nepenthes exhibited by M. Alex. Dallière of Ghent were much inferior to the plants we are accustomed to see in English gardens. In spite of the season-all hyacinths grown in the open air had long been past-one room was resplendent with remarkably fine pot hyacinths contributed by several Dutch growers.

The new Bertolonias exhibited by Van Houtte attracted much attention ; it is impossible to describe the delicacy as well as the brilliancy of their foliage.

Saintpaulia ionantha, a gesneraceous plant with a rosette of radical leaves and short scapes, bearing deep violet blue, yellow-anthered flowers, was one of the prettiest as well as one of the most interesting new plants exhibited. Seeds of it were sent home by the German officer (in whose honour it has been named) from the mountains of Eastern Tropical Africa. In general aspect the plant resembles Ramondia pyrenaica.

In British gardens, Bromeliads have not yet acquired the position to which they are entitled as ornamental plants; many of them are very handsome and their strangely marbled leaves and brilliantly-coloured inflorescences, which often last a long time, make them popular on the continent for decorative purposes. Many thousands of one species alone-beautifully grown plants-were seen in the Royal Gardens at Laeken, where Mr. Knight uses them with great effect. At the exhibition were to be seen many fine hybrids; some of the best were those shown by M. Duval of Versailles, under the names of Vriesea tessellata, splendens, and its varieties major and minor. Other very fine Bromeliads were exhibited by the Botanic Garden at Liège-for so many years

U 77405 . 
famous for its collections of this family of plants,-by MM. Jacob Makoy \& Co., and by M. J. Moens.

Crotons I have seen much better shown in England.

In the large annexe beautiful colour effects were produced by masses of Azalea mollis, Rhododendrons shown in fine variety by M. Pynaert, Azalea indica, Clivia miniata, vars., \&c. One of the most successful efforts in the way of plant cultivation I have ever seen were the oranges Citrus sinensis) from M. Gulinck and M. Alexis Dallière; the plants were fine bushes and pyramids, 2 to 3 feet high, laden with well coloured fruits.

Kalmia latifolia, dense, compact bushes covered with flowers, were exhibited in quantity; a more elegant pot plant could scarcely be imagined than this as grown at Ghent.

The Sweet Bay (Laurus nobilis) is cultivated in some establishments near Ghent and elsewhere in Belgium by the acre. They are grown in tubs as round-headed bushes on stems or as pyramids, and as specimens, showing great skill on the part of the grower, they leave nothing to be desired. During winter the plants must be housed; they require so long a time to attain a marketable size and so much care to bring them to such a state of perfection that they are much too valuable to risk outside during winter.

Choisya ternata was well grown and flowered. Some specinens had hemispherical heads, on stems 2 feet high, covered with blossoms. Cytisus scoparius, var. andreanus, was also exhibited, grown in a similar way.

Diervilla (or Weigela), Eva Ratke, is a handsome variety with deep red flowers; it was finely exhibited by $\mathbf{M}$. Pynaert, and will doubtless be cultivated by all who love hardy shrubs.

At Laeken a bronzy yellow tea rose, William Morley, is grown under glass for cutting, and is preferred to Maréchal Niel, as it is not so liable to canker as that variety. Standard hybrid perpetual roses and dwarf moss roses were largely grown in pots and well done. In a bed in one of the large conservatories a fine mass of Strelitzia Regina was in flower; it was planted out; the temperature in winter was kept up to $15^{\circ}-16^{\circ}$ Centigrade (say $60^{\circ}$ Fahrenheit). Amongst other striking plants planted out at Laeken are Clavijas, Bromeliads, Chamarops stauracantha-a remarkably fine specimen,-Kentia Lindeni, and other rare palms. Brunfelsias in fine flower produced beautiful effects as bushes planted out.

Large plants of Vanda tricolor, \&c., grown elsewhere and brought into the large warm conservatory to flower, were models of good cultivation. A number of small bushes-not a foot high, in six-inch pots-of Medinilla magnifica bore as many as half a dozen fine inflorescences; these must have been raised from large cuttings taken from old plints after growth had been made and bloom buds more or less formed. In any case the Medinillas were $a$ triumph of gardening skill.

One of the great features in the spring months at Laeken is the great extent of corridor connecting the different groups of houses with the palace and with each other. There are about 1,200 yards of corridor, and in mid April it was a blaze of flower. Tropæolums, ivf-leaved and zonal Pelargoniums, Abutilon megapotamicum (A. vexillarium), which was also used with considerable effect as a basket plant, Passion flowers, Heliotropes, Jasmines, the true Acacia riceana, Rhodochiton volubile, Dolichos, Bignonias, and other plants being trained up the side and roofs. 
Columbines were largely grown as pot plants for decorative furnishing, and remarkably fine they were.

G. N.

\section{CCCXXI.-ECONOMIC PLANTS OF SIERRA LEONE.}

A report on the botany and geology of the district of Sierra Leene traversed by the Anglo-French Boundary Commission in 1892 has lately been issued by the Colonial Office. It is prepared by Mr. G. F. Scott Elliot, F.L.S., the botanist to the Commission, with notes on the geology by Miss Catharine A. Raisin, B. Sc. of University College.

From the botanical portion of the report the following references to the economic plants of Sierra Leone are of interest. It may be remembered that an account of the fruit productions of Sierra Leone was given in the Kew Bulletin, 1888, p. 221 :-

\section{CofFeE.}

Coffee was discovered wild at Sierra Leone so long ago as 1796 by Mr. A. Moore. At present there are two different species cultivated by the natives, and these require different treatment.

Coffea stenophylla.-The narrow-leaved " wild," " bush," or " native cotfee," is sometimes found wild in the hills, and is more often cultivated by the natives than the Liberian. It grows very freely, and appears to yield quite as much as the Liberian, bui it is somewhat longer in coming into bearing. Both the natives and French traders at Freetown say that it has a superior flavour, and prefer it to the Liberian. In fact, latterly, a certain amount has been exported to a wholesale French dealer, who is said to sell it at 4 francs 50 centimes a lb. as "best Mocha." Considering that it is worth in Freetown about 6d. a lb., this should be a fairly profitable trade, and a trial shipment should be made by the English merchants to find out exactly what the market value in Liverpool would be. The plant appears to thrive best on the higher hills about Sierra Leone, on gneissose or granitic soil, and can be grown from 500 to 2,000 feet. Probably it may be grown both above and below these limits.

Coffea liberica.-There is no doubt that the cultivation of this coffee is extremely profitable in the Sierra Leone district. There is one well established plantation, and bushes may constantly be seen in native enclosures. The Hon. S. Lewis was kind enough to show me over his plantation at Christiansville, which probably contains some 70,000 trees, and gave me every information with regard to it. It was commenced in 1883, and of course was in its initial stages both extremely expensive and disappointing. Now, however, Mr. Lewis thinks he has advanced beyond the experimental stage, and he certainly seems to be gaining the reward which his enterprise and perseverance so well deserve.

\section{RUBBER.}

The amount of rubber available from the rubber-vines of West Africa (species of Landolphia) depends on the amount of original forest, and this is not large in the district we traversed. On the other hand, there are enormous areas from which rubber could be obtained, 